\title{
Pacific Northwest Laboratory Quarterly Report to Advanced Nuclear Energy Systems, Space and Special Purposes Division for April-June 1975
}

July 1975

Prepared for the U.S. Energy Research and Development Administration under Contract E(45-1): 1830 


\section{NOTICE}

This report was prepared as an account of work sponsored by the United States Government. Neither the United States nor the United States Energy Research and Development Administration, nor any of their employees, nor any of their contractors, subcontractors, or their employees, makes any warranty, express or implied, or assumes any legal liability or responsibility for the accuracy, completeness or usefulness of any information, apparatus, product or process disclosed, or represents that its use would not infringe privately owned rights.

\section{PACIFIC NORTHWEST LABORATORY operated by \\ BATTELLE \\ for the}

U.S. ENERGY RESEARCH AND DEVELOPMENT ADMINISTRATION

Under Contract E(45-1)-1830

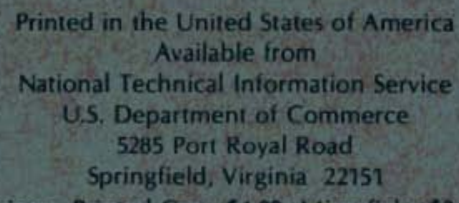

Price: Printed Copy \$4.00; Microfiche \$2.25 


\section{ERRATA FOR APRIL PROGRESS REPORT (BNWL-1845-10)}

1. Page 8 - Lines 11-13 should read "At the higher temperatures, the WESF-grade $\mathrm{SrF}_{2}$ showed the highest diffusivity, the commercial-grade the lowest values, and the high-purity grade intermediate values."

2. Page 9 - Figure 3 - The scale on the ordinate is incorrect with the zero point (base line) displaced two units.

3. Page 12 - Line 2 - The definition for $\lambda$ should read "where $\lambda$ is the thermal conductivity in $\mathrm{cal} / \mathrm{cm}-{ }^{\circ} \mathrm{C}-\mathrm{sec} "$. 
BNWL - 1845-12

UC -23

PACIFIC NORTHWEST LABORATORY QUARTERLY REPORT

TO ADVANCED NUCLEAR ENERGY SYSTEMS, SPACE AND SPECIAL PURPOSES DIVISION

FOR APRIL-JUNE 1975

by

H. T. Fullam

July 1975

Battelle

Pacific Northwest Laboratories

Richland, Washington 99352 


\section{SUMMARY}

Based on the results of the short-term compatibility tests, Haynes 25 , Hastelloy $\mathrm{C}-276$, and TZM have been selected as the optimum materials for long-term testing with WESF ${ }^{90} \mathrm{SrF}_{2}$. The tests will be carried out at 600 , 800 , and $1000^{\circ} \mathrm{C}$ and last up to 30,000 hours.

The effect of temperature on the dissolution of $\mathrm{SrF}_{2}$ in demineralized water and seawater was studied. As expected, the dissolution rate of the fluoride increased rapidly as the water temperature increased.

The specific heat, thermal expansion and thermal conductivity of three grades of nonradioactive strontium fluoride were measured as a function of temperature. For all three grades of $\mathrm{SrF}_{2}$ the heat capacity increased with temperature up to about $560^{\circ} \mathrm{K}$ and remained constant, thereafter, at a value of $0.15 \mathrm{cal} / \mathrm{g}-{ }^{\circ} \mathrm{C}$. The thermal expansion varied slightly between the different grades of fluoride, but the average value was approximately $2 \times 10^{-5} \mathrm{~cm} / \mathrm{cm}{ }^{\circ} \mathrm{C}$ over a temperature range of $50-700^{\circ} \mathrm{C}$. The thermal diffusivity also varied slightly between the three grades of fluoride. The average values at $100^{\circ} \mathrm{C}$ and $850^{\circ} \mathrm{C}$ are $20 \times 10^{-3}$ and $5 \times 10^{-3}$ $\mathrm{cm}^{2} / \mathrm{sec}$ respectively. 


\section{CONTENTS}

SUMMARY ............................

LIST OF FIGURES . . . . . . . . . . . . . v v

LIST OF TABLES. ...................... vi

STRONTIUM HEAT SOURCE DEVELOPMENT PROGRAM ....... 1

Long-Term Compatibility Tests. . . . . . . 1

$\mathrm{SrF}_{2}$ Dissolution Rate Study......... 2

Thermodynamic Calculations ......... 2

$\mathrm{SrF}_{2}$ Physical Property Measurements. . . . . . 2 


\section{$\underline{\text { LIST OF FIGURES }}$}

1 Specific Heat of $\mathrm{SrF}_{2} \ldots \ldots \ldots \ldots$

2 Thermal Expansion of $\mathrm{SrF}_{2} \ldots \ldots 10$

3 Thermal Diffusivity versus Temperature for Commercial-Grade $\mathrm{SrF}_{2} \ldots \ldots \ldots 11$

4 Thermal Diffusivity versus Temperature for WESF-Grade $\mathrm{SrF}_{2}$. . . . . . . . . . 12

5 Therma1 Diffusivity versus Temperature for High-Purity $\mathrm{SrF}_{2} \ldots \ldots . . . . . . . .13$

6 Thermal Resistivity as a Function of Temperature for Various Grades of $\mathrm{SrF}_{2} \ldots \ldots$ 


\section{LIST OF TABLES}

1 Composition and Thermal History of

$\mathrm{SrF}_{2}$ Used in Dissolution Rate Studies. . . . . . . 3

2 Effect of Temperature on the Dissolution

Rate of Strontium Fluoride ........... 4

3 Specific Heat of Strontium Fluoride. . . . . . 8

4 Thermal Expansion Coefficients of $\mathrm{SrF}_{2} \ldots . . . .9$

5 Thermal Diffusivity of $\mathrm{SrF}_{2}$. . . . . . . . . 14

6 Values of Constants for Equations of

Thermal Resistivity Plots $(1 / \lambda=A+B T)$. . . . . 15 


\author{
PACIFIC NORTHWEST LABORATORY \\ QUARTERLY REPORT TO \\ ADVANCED NUCLEAR ENERGY SYSTEMS, \\ SPACE AND SPECIAL PURPOSES DIVISION
}

FOR APRIL - JUNE 1975

\title{
STRONTIUM HEAT SOURCE DEVELOPMENT PROGRAM
}

At Hanford, strontium will be separated from the highlevel waste, converted to the fluoride, and doubly encopsulated in small, high-integrity containers for subsequent long-term storage. The fluoride conversion, encopsulation and storage will take place in the Waste Encapsulation and Storage Facilities (WESE). The encapsulated strontium fluoride represents an economical source of ${ }^{90} \mathrm{Sr}$ if the WESF capsule can be licensed for heat source applications under anticipated use conditions. The objectives of this program are to obtain the data needed to Iicense $90 \mathrm{SrF}_{2}$ heat sources and specifically the WESF $90 \mathrm{SrF}_{2}$ capsules. The information needed for licensing can be divi.ded into three generat areas:

\section{Long-term $\mathrm{SrF}_{2}$ compatibility data.}

2. Chemical and physical property data on $90{ }_{S r} F_{2}$.

3. Capsule property data such as extemal corrosion resistance, crush strength, etc.

The current progroon is designed to provide the required information.

\section{LONG-TERM COMPATIBILITY TESTS}

Based on the results of the short-term compatibility tests, three containment materials will be evaluated in the long-term compatibility tests; they are TZM, Haynes 25, and Hastelloy C-276. It is current1y planned that the tests will be carried out at 600,800 , and $1000^{\circ} \mathrm{C}$ and will last 2200, 8800, 17,600, and 30,000 hours. Both nonradioactive SrF 2 and fuel-grade ${ }^{90} \mathrm{SrF}_{2}\left(50-55 \%{ }^{90} \mathrm{Sr}\right.$ isotopic content) produced by ARHCO will be evaluated in the tests. The tests are designed to provide mechanical property data as well as compatibility data on the three alloys. A11 of the hardware required for the tests has been fabricated except for a few Charpy $V$ Notch test specimens. Fuel-grade ${ }^{90} \mathrm{SrF}_{2}$ will be 
available from ARHCO in the second quarter of FY-76. The tests wi11 start as soon as the test couples can be fabricated after the ${ }^{90} \mathrm{SrF}_{2}$ is obtained.

Work continues on preparation of a topical report summarizing the results of the short-term compatibility tests.

$\underline{S r F}_{2}$ DISSOLUTION RATE STUDY

A number of tests were carried out to determine the effect of temperature on the dissolution rate of nonradioactive $\mathrm{SrF}_{2}$ in demineralized water and seawater. The dynamic procedure described earlier (BNWL-18453) was used for the tests. Two grades of $\mathrm{SrF}_{2}$ were evaluated. The compositions, surface areas, and thermal history of the $\mathrm{SrF}_{2}$ samples tested are given in Table 1. The results obtained in demineralized water and seawater at various temperatures are summarized in Table 2. As expected, the dissolution rates of the various fluoride samples increased very rapidly as the water temperature increased.

Additional dissolution rate studies have been halted by a failure of the metering pump. The pump has been returned to the manufacturer for repair. As soon as the repairs are effected, the dissolution rate studies will be resumed.

THERMODYNAMIC CALCULATIONS

The preliminary thermodynamic analysis of WESF ${ }^{90} \mathrm{SrF}_{2}$ containment alloy systems has been completed and the results presented in earlier reports. A more detailed analys is of the three systems to be evaluated in the long-term compatibility tests has been carried out by $\mathrm{Dr}$. Carl Alexander and his associates at Battelle's Columbus Laboratories. The results of the analyses will be presented as soon as they are received from $\mathrm{Dr}$. Alexander. The three systems evaluated in the analyses are: WESF ${ }^{90} \mathrm{SrF}_{2}$-Haynes 25 , WESF ${ }^{90} \mathrm{SrF}_{2}$-Hastelloy C-276, and WESF ${ }^{90} \mathrm{SrF}_{2}-\mathrm{TZM}$. $\mathrm{SrF}_{2}$ PHYSICAL PROPERTY MEASUREMENTS (G. B. Mellinger and J. L. Bates)

The thermal properties of $\mathrm{SrF}_{2}$ are important in evaluating the thermal conditions of encapsulated, radioactive $\mathrm{SrF}_{2}$. The purpose of 


\title{
TABLE 1. Composition and Thermal History of
}

$\mathrm{SrF}_{2}$ Used in Dissolution Rate Studies

\author{
Sample No. \\ Description of Material \\ Surface Area \\ $S R-3 B$ \\ High-purity $\mathrm{SrF}_{2}<0.1 \%$ total impurities \\ fused at $1550^{\circ} \mathrm{C}$, cooled and crushed to \\ $-1 / 4^{\prime \prime}+1 / 8^{\prime \prime}$ granules. \\ SR-8A WESF-grade $\mathrm{SrF}_{2}$ powder* fused at $1550^{\circ} \mathrm{C}$, \\ cooled and crushed to $-1 / 4^{\prime \prime}+1 / 8^{\prime \prime}$ \\ $\mathrm{Cm}^{2} / \mathrm{g} \mathrm{SrF} 2$ \\ 620 \\ 480 \\ granules. \\ SR-8B WESF-grade SrF $\mathrm{S}_{2}$ powder* fired at $1100^{\circ} \mathrm{C}$ \\ for 1 hour, crushed to $-1 / 4^{\prime \prime}+1 / 8 "$ \\ 440 \\ granules. \\ SR-8C WESF-grade SrF, powder* fired at $1100^{\circ} \mathrm{C}$ \\ for 16 hours, crushed to $-1 / 4^{\prime \prime}+1 / 8^{\prime \prime}$ \\ 820 \\ *Composition corresponds to composition of WESF ${ }^{90} \mathrm{SrF}_{2}(\sim 95.5 \%$ \\ purity).
}


TABLE 2. Effect of Temperature on the Dissolution Rate of Strontium Fluoride

\begin{tabular}{|c|c|c|c|c|c|c|c|c|c|c|c|c|c|c|c|c|}
\hline \multirow{4}{*}{$\begin{array}{l}\text { Temp. } \\
\left({ }^{\circ} \mathrm{C}\right)\end{array}$} & \multicolumn{16}{|c|}{ Dissoluticn Rate } \\
\hline & \multicolumn{8}{|c|}{$\mu \mathrm{g} \mathrm{Sr}$ Dissolved/g Sr Present } & \multicolumn{8}{|c|}{ ug Sr Dissolved $/ \mathrm{cm}^{2}$ Surface firea } \\
\hline & \multicolumn{4}{|c|}{ Demineralized Water } & \multicolumn{4}{|c|}{ Seawater } & \multicolumn{4}{|c|}{ Demineralized Water } & \multicolumn{4}{|c|}{ Seawater } \\
\hline & $S R-3 B$ & $S R-8 A$ & $S R-8 B$ & $S R-8 C$ & $S R-3 B$ & $S R-8 A$ & $S R-8 B$ & $S R-8 C$ & $S R-3 B$ & $S R-8 A$ & $S R-8 B$ & $S R-8 C$ & $S R-3 B$ & SR-8A & $S R-8 B$ & $S R-8 C$ \\
\hline 3 & 83 & 74 & 73 & 93 & 41 & 31 & 32 & 39 & 0.093 & 0.10 & 0.11 & 0.075 & 0.046 & 0.043 & 0.048 & \\
\hline 9 & 99 & 77 & 76 & 96 & 47 & 36 & 44 & 51 & 0.11 & 0.11 & 0.12 & 0.078 & 0.053 & 0.050 & 0.067 & \\
\hline 24 & $\begin{array}{l}170 \\
190\end{array}$ & 150 & $\begin{array}{l}100 \\
150\end{array}$ & 200 & 83 & 72 & 75 & 93 & $\begin{array}{l}0.19 \\
0.21\end{array}$ & 0.21 & $\begin{array}{l}0.15 \\
0.23\end{array}$ & 0.16 & 0.094 & 0.10 & 0.11 & \\
\hline 34 & 300 & $240^{\circ}$ & 250 & 330 & & & & & 0.24 & 0.33 & 0.38 & 0.27 & & & & \\
\hline 35 & 400 & 360 & 300 & 500 & & & & & 0.45 & 0.50 & 0.45 & 0.41 & & & & \\
\hline 42 & 380 & 310 & 300 & 490 & 140 & 120 & 130 & 150 & 0.73 & 0.43 & 0.45 & 0.40 & 0.76 & 0.17 & 0.20 & \\
\hline 58 & 700 & & & & & & & & 0.79 & & & & & & & \\
\hline 61. & 760 & 680 & 680 & 740 & & & & & 0.86 & 0.94 & 1.0 & 0.60 & & & & \\
\hline 81 & 2460 & 1960 & 1920 & 2420 & & & & & 2.8 & 2.7 & 2.9 & 2.0 & & & & \\
\hline
\end{tabular}


these studies was to measure the specific heat, thermal expansion, and thermal diffusivity of strontium fluoride as a function of temperature. Since the radioactivity associated with ${ }^{90} \mathrm{SrF}_{2}$ does not affect these properties significantly, the measurements were made using nonradioactive $\mathrm{SrF}_{2}$.

Three grades of nonradioactive strontium fluoride were used in the measurements.

1. High-purity $\mathrm{SrF}_{2}$ containing less than $1000 \mathrm{ppm}$ total impurities.

2. Commercial $\mathrm{SrF}_{2}$ containing approximately 0.5 wt $\%$ impurities ( $\mathrm{Na}, \mathrm{Ca}, \mathrm{Ba}$, and $\mathrm{SO}_{4}=$ were the principal impurities).

3. WESF-grade $\mathrm{SrF}_{2}-\mathrm{A}$ mixture of fluorides approximating the composition of WESF-produced ${ }^{2} \mathrm{SrF}_{2}$ (contains approximately $5 \%$ impurities).

Each grade of fluoride was fired at $1100^{\circ} \mathrm{C}$ for 16 hours in air and ball milled to -100 mesh prior to use.

\section{Sample Preparation}

The $\mathrm{SrF}_{2}$ samples were prepared by pressing $\mathrm{SrF}_{2}$ powder into discs and right cylinders with subsequent sintering in air. The powders were initially pressed at $4000,12,000$, and $20,000 \mathrm{psi}$ and sintered at $800^{\circ} \mathrm{C}$. Other samples were pressed at $43,700 \mathrm{psi}$ and sintered at $1000^{\circ} \mathrm{C}$. Discs $0.635 \mathrm{~cm}$ in diameter and $0.050 \mathrm{~cm}$ thick were used for thermal diffusivity and heat capacity measurements. Right cylinders approximately $1.9 \mathrm{~cm}$ long and $0.635 \mathrm{~cm}$ in diameter were used for measuring the thermal expansion.

Property measurements were complicated by sample changes which occurred during heating at the higher temperatures, and from laminations in the sample discs. In order to obtain consistent heat capacity results, the $\mathrm{SrF}_{2}$ discs were heated in air at $500^{\circ} \mathrm{C}$ for 2 hours. This eliminated the presence of unknown constituents thought to be water vapor or organic die lubricant (used in pressing the samples). Heat capacity measurements were made after heating and with minimum exposure to the atmosphere. The thermal diffusivity samples were laminated as fabricated and easily broke when hand-ground to the desired disc thicknesses. 
Ultimately, the new samples without lamination were fabricated by being pressed at $43,271 \mathrm{psi}$ and sintered at $1000^{\circ} \mathrm{C}$. Thermal diffusivity samples were coated with graphite to minimize penetration of the laser beam optical path from the detector beyond the sample surface into the solid.

Specific Heat

The specific heats of the $\mathrm{SrF}_{2}$ were measured using a differential scanning calorimeter. A sample disc was subjected to a linear temperature increase with the heat flow into the sample and a reference being continuously measured. Under these conditions, the heat flow is proportional to the instantaneous specific heat of the sample. Two holders are mounted symmetrically inside an enclosure initially at room temperature. The temperature control system controls the average temperature of the two holders with platinum resistance thermometers and with resistance heating elements embedded in the holders. A secondary temperature control system measures the difference between the two holders and adjusts this difference to zero by controlling a differential component of the total heating power. This differential power is measured. Knowing the constants of the system and the temperature rate change, the specific heat can be calculated. The absolute determination of these parameters can be eliminated if a material of known specific heat is placed in the reference holder. This reference is then used to calibrate the instrument. A specific heat of $\alpha-\mathrm{Al}_{2} \mathrm{O}_{3}$ is known to five significant figures between $0^{\circ}$ and $1200^{\circ} \mathrm{K}$. For this study, an $\alpha-\mathrm{Al}_{2} \mathrm{O}_{3}$ single crystal was used to calibrate the calorimeter. The data indicate an error of less than $2 \%$.

Specific heats were measured from $320^{\circ}$ to $710^{\circ} \mathrm{K}$ for commercial-grade, WESF-grade, and high-purity $\mathrm{SrF}_{2}$ using specimens pressed at 2 and 10 tons.

The specific heats of the three grades of $\mathrm{SrF}_{2}$ are shown in Figure 1. The specific heat of the samples pressed at 2 and 10 tons were the same within experimental error. All three compositions showed an increase in heat capacity with increasing temperature reaching a near- 

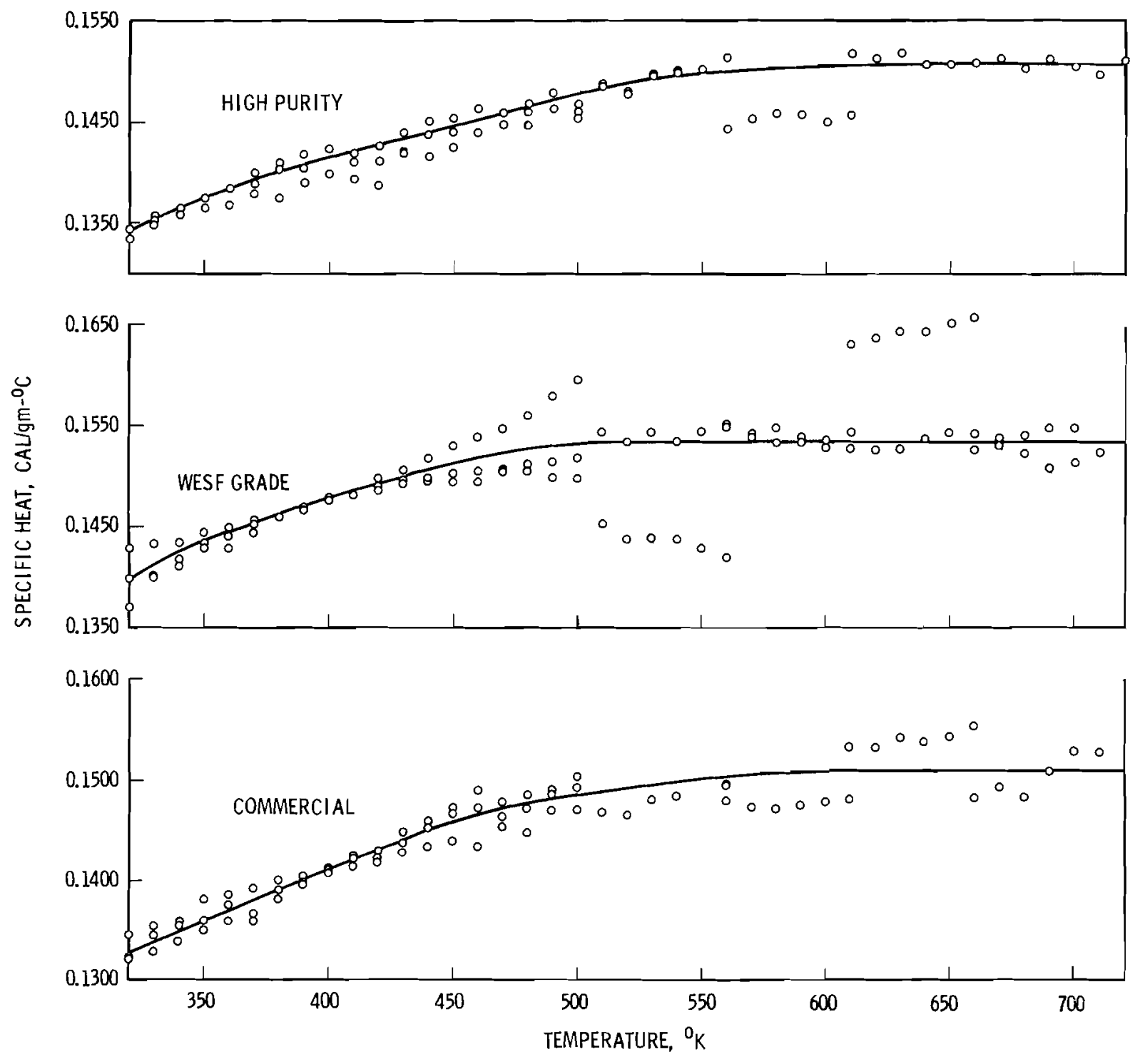

FIGURE 1. Specific Heat of $\mathrm{SrF}_{2}$ 
constant value above $500^{\circ} \mathrm{K}$. The initial values at $320^{\circ} \mathrm{K}$, constant heat capacity values, and the temperatures where $C_{p}$ approaches a constant for each $\mathrm{SrF}_{2}$ sample are tabulated in Table 3 . The final values were the same for all three $\mathrm{SrF}_{2}$ samples within experimental errors. Scatter in the data was observed at higher temperatures. This is attributed to irregularities in the heating system which occurred after replacement of heating elements which had failed.

TABLE 3. Specific Heat of Strontium Fluoride

\begin{tabular}{|c|c|c|c|c|}
\hline Grade of $\mathrm{SrF}_{2}$ & $\begin{array}{l}\text { Initial }{ }^{C} \\
\text { cal/g }-{ }^{\circ}{ }^{p} \\
\end{array}$ & 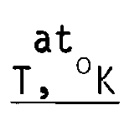 & $\begin{array}{l}\text { Final } \mathrm{C} \\
\mathrm{Ca} / \mathrm{a}-{ }^{\circ} \mathrm{C}\end{array}$ & ${ }_{T}^{a t}{ }^{o} K$ \\
\hline Commercial & 0.1330 & 320 & $0.1510 \pm 0.0025$ & 560 \\
\hline WESF-Grade & 0.1395 & 320 & $1.1537 \pm 0.0015$ & 520 \\
\hline High-Purity & 0.1340 & 320 & $0.1510 \pm 0.0010$ & 560 \\
\hline
\end{tabular}

Thermal Expansion

The thermal expansion of the commercial-grade, WESF-grade, and highpurity $\mathrm{SrF}_{2}$ were measured from near room temperature to $700^{\circ} \mathrm{C}$. Each sample was measured twice, except for the high-purity which was measured three times.

Measurements were made using a quartz push rod dilatometer. The temperature was increased linearly with a proportional controller and programmer. The increase in length of the sample was measured with a transducer positioned at one end of the quartz push rod. The transducer signal can be recorded to $\pm 0.017 \%$ (0.07\% for $1.90 \mathrm{~cm}$ long sample).

The samples were $1.90 \mathrm{~cm}$ long and $0.64 \mathrm{~cm}$ in diameter. Each end of the sample was machined with a rounded end to maintain alignment. The width and length of each sample were measured before and after the thermal expansion tests.

Data points were calculated at $\sim 50^{\circ} \mathrm{C}$ intervals from the continuous sample length and temperature curves. Changes in sample composition, presumably due to fluoride or other vapor loss, occurred above $750^{\circ} \mathrm{C}$ for all three compositions. This prevented measurements to higher temperatures and resulted in irregularities in expansion results. 
The thermal expansion data is shown in Figure 2. The apparent decrease in expansion coefficient above $600^{\circ} \mathrm{C}$ in the commercial-grade is apparently due to composition changes. The greatest expansion is exhib$i$ ted by the WESF-grade $S_{r F}$. The values for the 1 inear thermal expansion coefficient are tabulated in Table 4.

TABLE 4. Thermal Expansion Coefficients of $\mathrm{SrF}_{2}$

\begin{tabular}{|c|c|c|}
\hline Composition & $\begin{array}{l}\text { Linear Thermal Expansion } \\
\text { Coefficient } \\
\left(\mathrm{cm} / \mathrm{cm}-{ }^{\circ} \mathrm{C} \times 10^{5}\right) \\
\end{array}$ & $\mathrm{T},{ }^{\circ} \mathrm{C}$ \\
\hline High-Purity & 2.13 & $50^{\circ}$ \\
\hline WESF-Grade & 2.19 & $50^{\circ}-700^{\circ} \mathrm{C}$ \\
\hline Commercial & 1.83 & $50^{\circ}-700^{\circ} \mathrm{C}$ \\
\hline
\end{tabular}

Thermal Diffusivity and Thermal Conductivity

The thermal diffusivities of the three $\mathrm{SrF}_{2}$ samples were measured using the pulsed laser technique. One surface of a thin sample disc, $0.064 \mathrm{~cm}$ thick, was heated with a short 3-7 joule heat pulse from a ruby laser. A heat pulse produced on the sample surface passed through the sample, and the temperature transient on the back surface of the sample was measured. The temperature change was displayed on an oscilliscope recorded on a photograph. The thermal diffusivity was determined from the shape of the temperature-versus-time curve. The over-all accuracy for measuring the tracing from the photograph is estimated to be $\pm 2 \%$.

The samples were heated in a resistance-heated furnace under 1 atmosphere of argon. The temperature was measured with a $\mathrm{W}-5 \%$ Re versus $\mathrm{W}-25 \%$ Re thermocouple positioned on the adjacent samiple holder and calibrated against a $\mathrm{Pt}-\mathrm{Pt} 10 \% \mathrm{Rh}$ thermocouple. The estimated accuracy of the temperature measurement was $\pm 3^{\circ} \mathrm{C}$.

The thermal diffusivities of the three grades of $\mathrm{SrF}_{2}$ are shown in Figures 3, 4, and 5. The diffusivity values for the three samples at various temperatures are tabulated in Table 5. Data are shown for WESFgrade and high-purity samples pressed at $45.271 \mathrm{psi}$ and sintered at $1000^{\circ} \mathrm{C}$, 


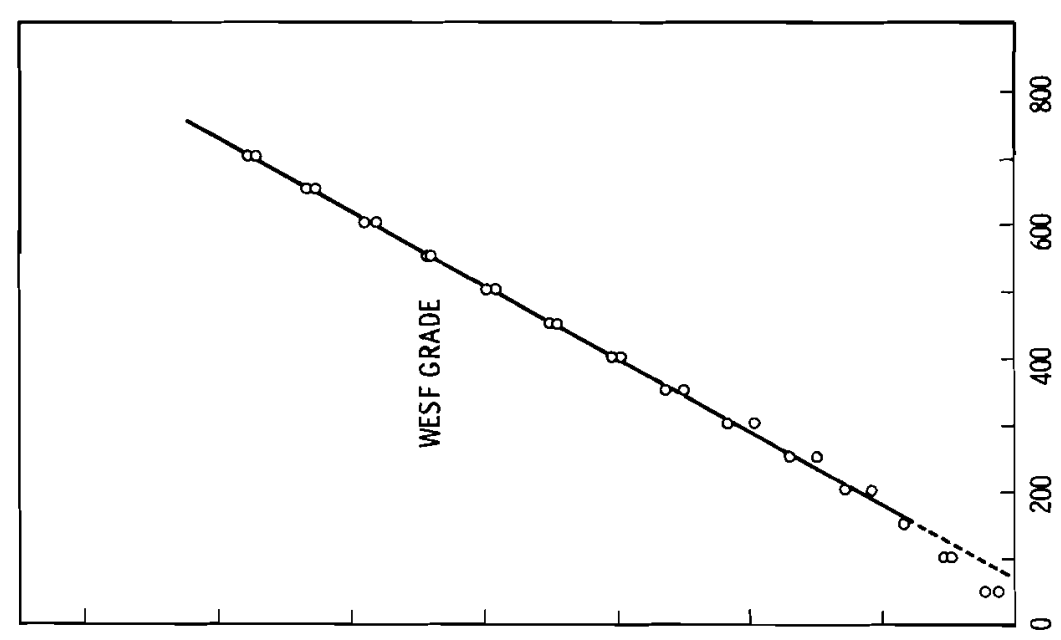

$\frac{u}{c}^{N}$

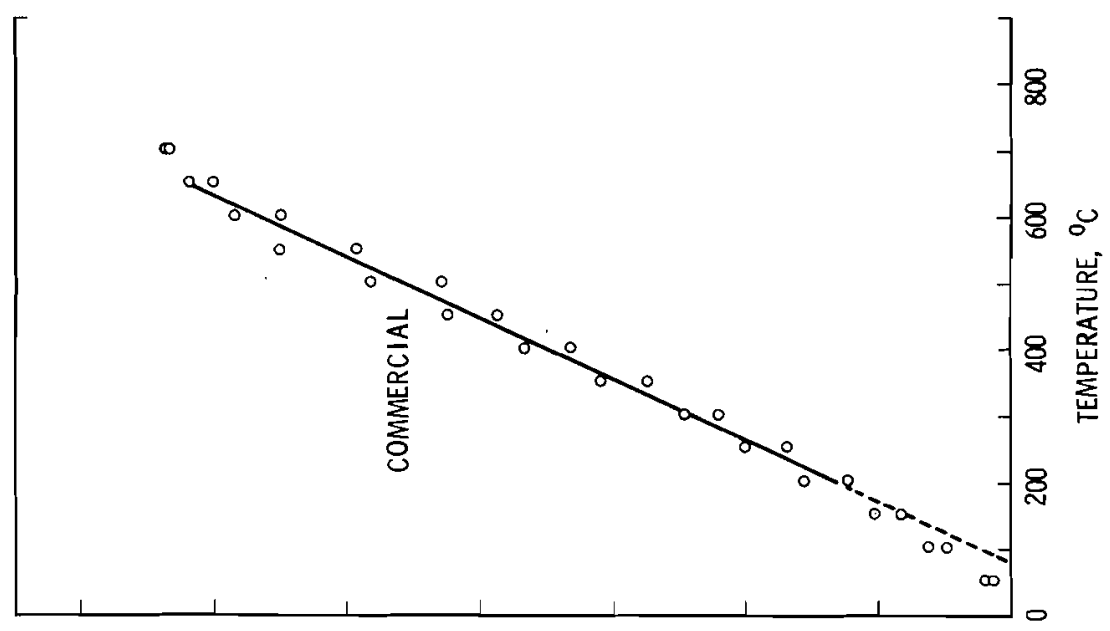

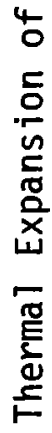

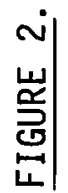

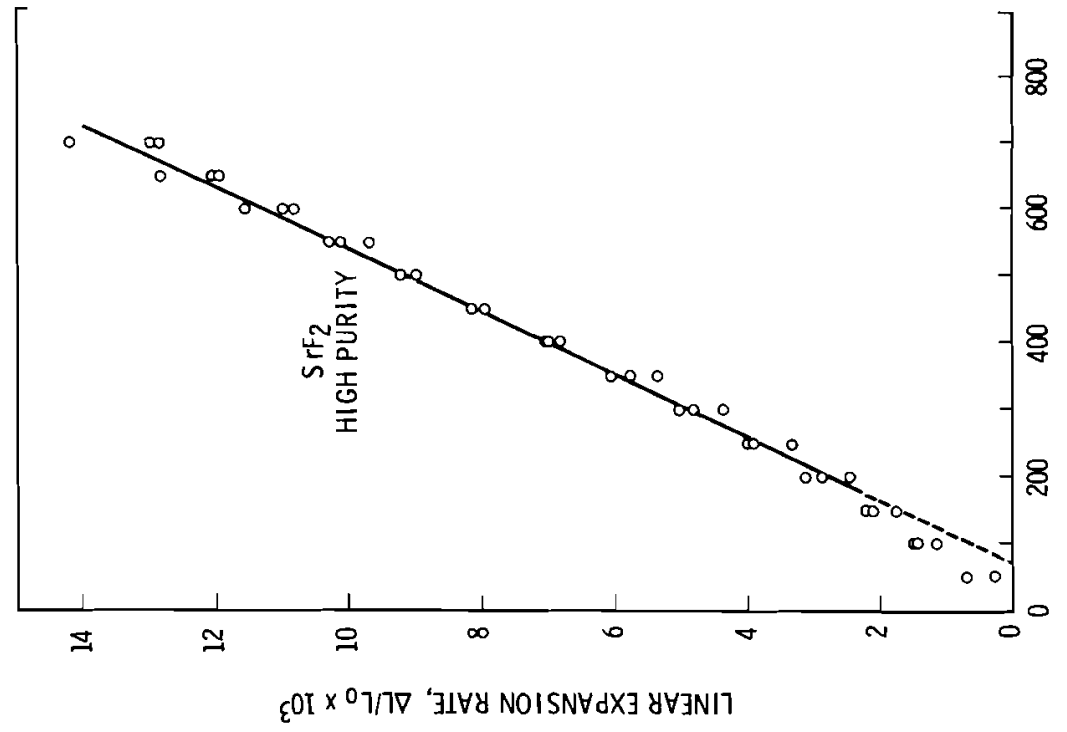




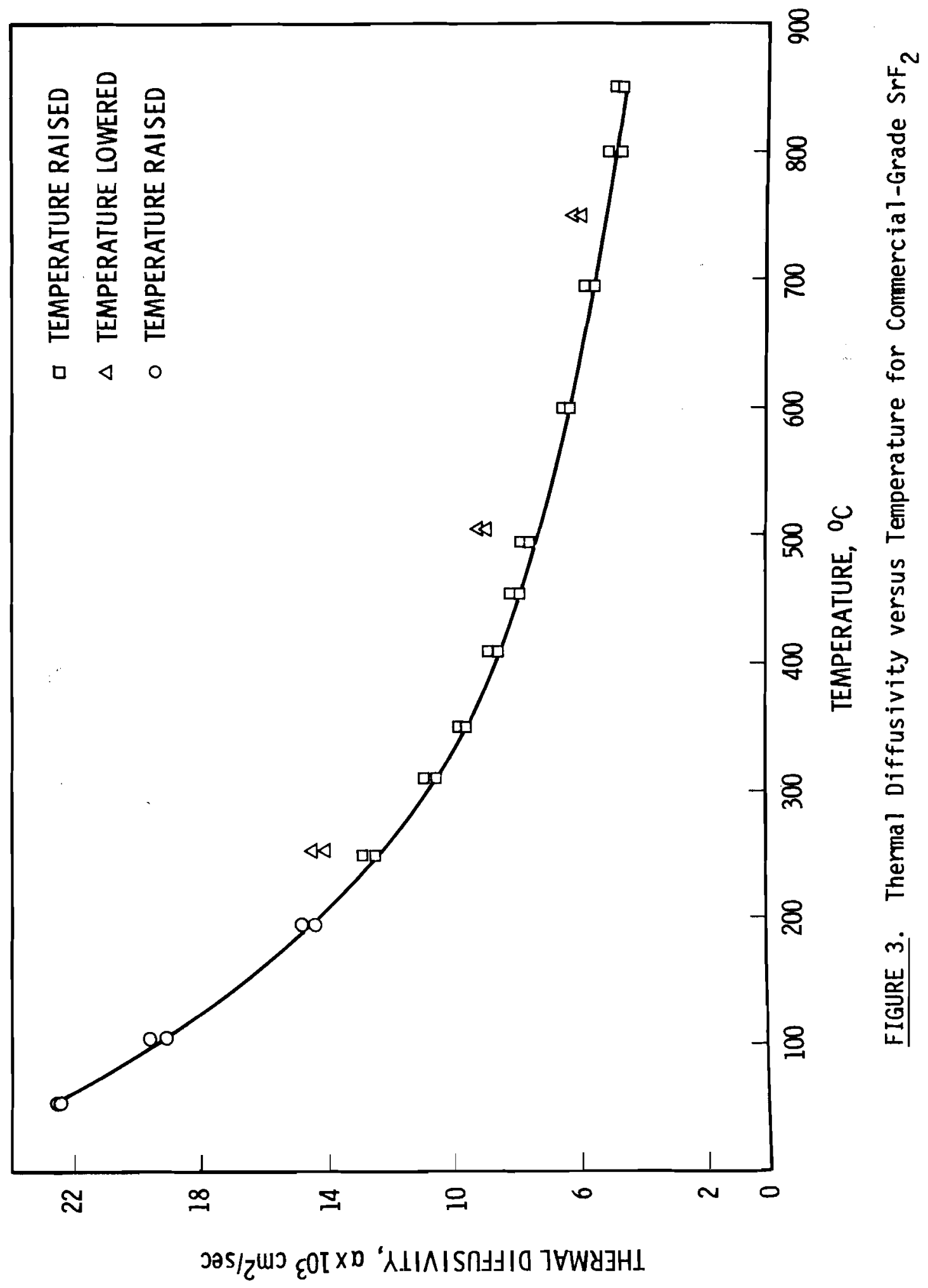




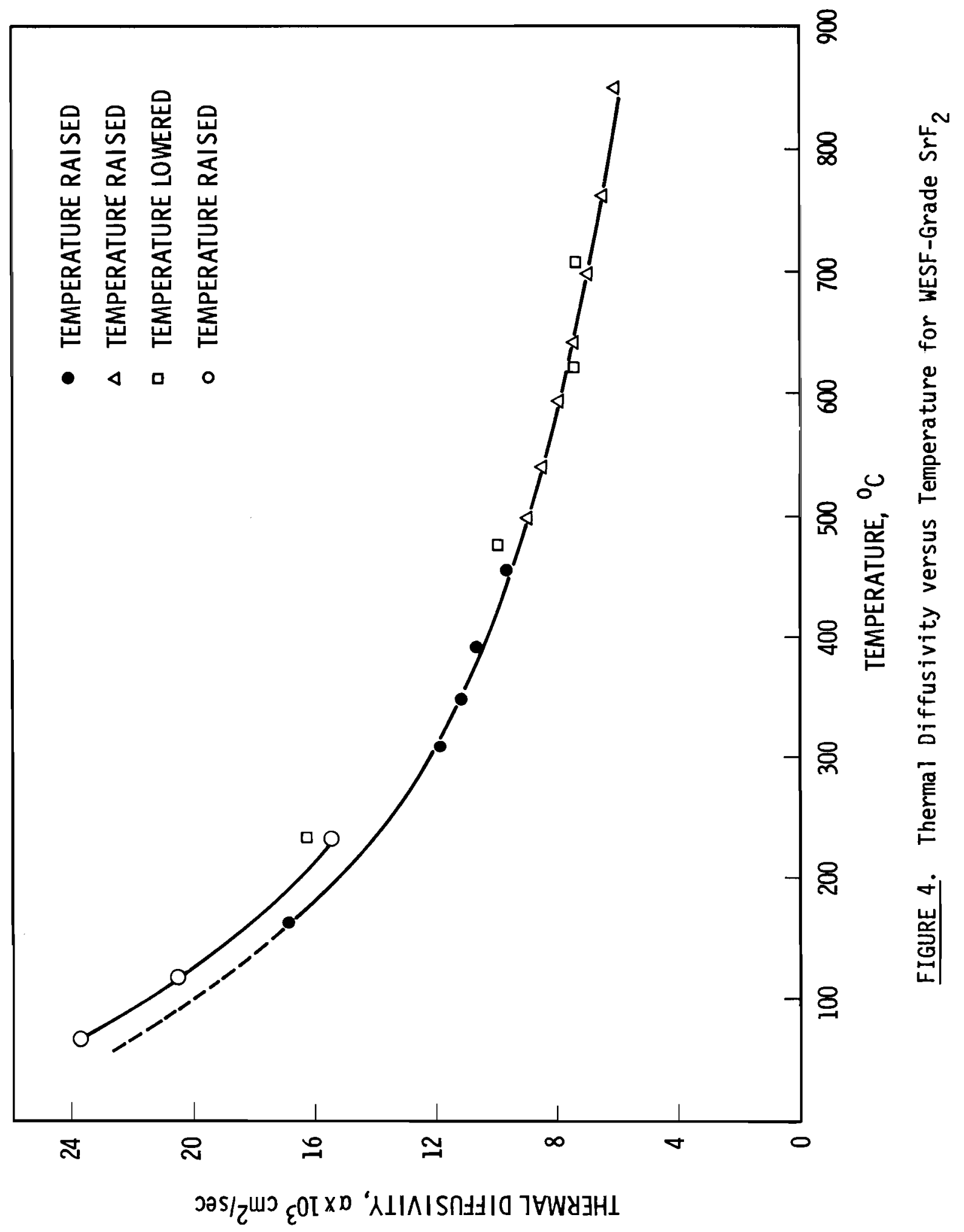




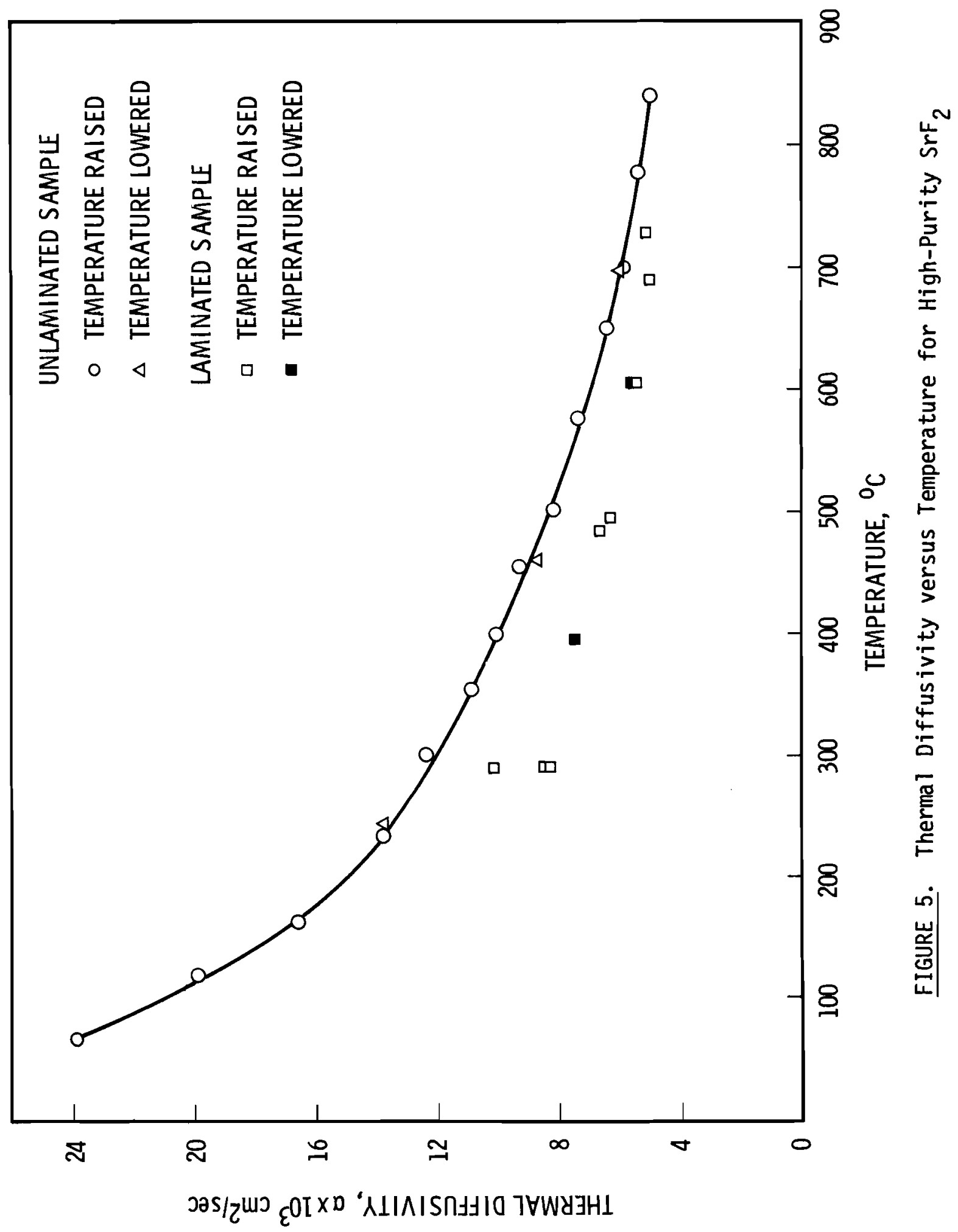


and a commercial-grade sample pressed at $4000 \mathrm{psi}$ and sintered at $800^{\circ} \mathrm{C}$. Data for a high-purity sample pressed at 12,000 psi and sintered at $800^{\circ} \mathrm{C}$ is also included. Inspection of this sample, however, showed extensive 1 aminations which were not present in the other samples. Al1 three unlaminated samples show the same general behavior. The thermal diffusivity decreased with increased temperature at the lower temperatures. This rate decreased as the temperature increased from 50 to $850^{\circ} \mathrm{C}$. At the higher temperatures, the WESF-grade $\mathrm{SrF}_{2}$ showed the highest diffusivity, the commercial-grade the lowest values, and the high-purity intermediate values. However, these differences between the three $\mathrm{SrF}_{2}$ samples without lamination are sma11 and could represent differences in fabrication as well as composition. For example, the laminated high-purity sample showed a consistently lower diffusivity than the unlaminated sample, with the values for both samples approaching each other at the higher temperatures. Thus, the thermal diffusivity of the $\mathrm{SrF}_{2}$ in the projected heat source wi11 probably be affected more by the laminations and voids present in the material than by differences in composition.

TABLE 5. Thermal Diffusivity of $\mathrm{SrF}_{2}$

\begin{tabular}{|c|c|c|c|}
\hline \multirow[b]{2}{*}{$\mathrm{T},{ }^{\circ} \mathrm{C}$} & \multicolumn{3}{|c|}{ Therma1 Diffusivity $(\alpha) \times 10^{3}, \mathrm{~cm}^{2} / \mathrm{sec}$} \\
\hline & Commercial-Grade & WESF-Grade & High-Purity \\
\hline 100 & 19.4 & 20.0 & 21.0 \\
\hline 350 & 9.7 & 11.2 & 11.0 \\
\hline 600 & 6.4 & 7.8 & 7.0 \\
\hline 850 & 4.6 & 5.9 & 4.9 \\
\hline
\end{tabular}

The thermal conductivity of a material was calculated from the product of the thermal diffusivity, heat capacity, and density.

$$
\begin{aligned}
& \lambda=\alpha \cdot C_{p} \cdot \rho \\
& \text { where } \lambda \text { is the thermal conductivity in cal } / \mathrm{cm}-{ }^{\circ} \mathrm{C}-\mathrm{sec} \\
& \alpha \text { is the thermal diffusivity in } \mathrm{cm}^{2} / \mathrm{sec}, \\
& C_{p} \text { is the heat capacity in cal } / \mathrm{g}-{ }^{\circ} \mathrm{C} \text {, and } \\
& \rho \text { is the density in } \mathrm{g} / \mathrm{cm}^{3}
\end{aligned}
$$


The values for $C_{p}$ were obtained from the previously-measured $C_{p}$. It was assumed that the $C_{p}$ remained constant at the higher temperature above $500^{\circ} \mathrm{C}$.

The density for thermal expansion was obtained from sample geometric measurements and sample weights. The following expression for density was used to calculate the thermal conductivity:

$$
\begin{aligned}
\rho_{T}= & \frac{\rho_{0}}{\left(1+\frac{\Delta \ell}{\ell_{0}}\right)^{3}} \\
\text { where } & \rho_{T}\left(\mathrm{~g} / \mathrm{cm}^{3}\right) \text { is the density at temperature } \mathrm{T}, \\
& \rho_{0}\left(\mathrm{~g} / \mathrm{cm}^{3}\right) \text { is the density at room temperature, and } \\
& \frac{\Delta \ell}{\ell_{0}} \text { is the linear expansion at temperature } T .
\end{aligned}
$$

The calculated thermal conductivities are shown in Figure 6 as $1 / \lambda$ versus $T$ (where $1 / \lambda$ is the thermal resistivity). The equation for the thermal conductivity versus temperature was expressed as $1 / \lambda=A+B T$, where $A$ and $B$ are constants. The WESF-grade and commercial-grade showed linear behavior within experimental error over the entire temperature range. The high-purity sample, however, exhibited a break in the $1 / \lambda$ versus $T$ curve near $400^{\circ} \mathrm{C}$. Two linear relationships were given to these regions. The constants A, B for the unlaminated $\mathrm{SrF}_{2}$ are shown in Table 6 and appear accurate to about $7 \%$.

TABLE 6. Values of Constants for Equations of Thermal Resistivity P1ots $(1 / \lambda=A+B T)$

Composition
Commercial
WESF-Grade
High-Purity

High-Purity

\begin{tabular}{rrr}
\multicolumn{1}{c}{$\mathrm{A}$} & & $\mathrm{B}$ \\
9.8 & & 0.098 \\
13.3 & & 0.069 \\
15.4 & & 0.067 \\
0.6 & & 0.104
\end{tabular}

Temperature Range

$$
\begin{array}{r}
50^{\circ}-850^{\circ} \mathrm{C} \\
50^{\circ}-850^{\circ} \mathrm{C} \\
150^{\circ}-400^{\circ} \mathrm{C} \\
400^{\circ}-850^{\circ} \mathrm{C}
\end{array}
$$




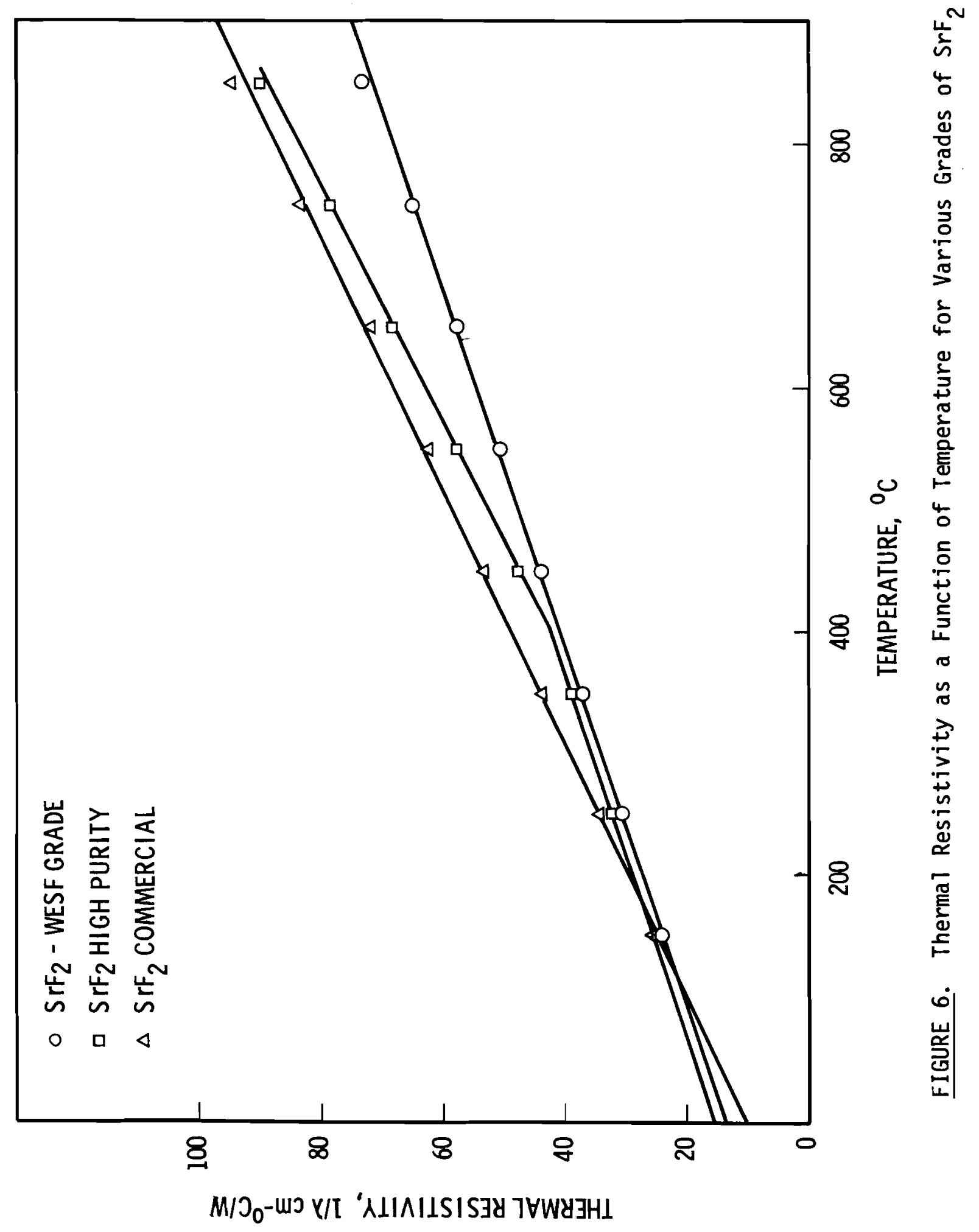




\section{DISTRIBUTION}

No. of

Copies

OFFSITE

1

1

1

11

1

1
ERDA Chicago Patent Attorney

9800 S. Cass Avenue

Argonne, IL 60439

A. A. Churm

ERDA Division of Biomedical and Environmental Research Washington, DC $205 \overline{45}$

J. N. Maddox

ERDA Division of Production and Materials Management Washington, DC 20545

F. P. Baranowski

ERDA Advanced Nuclear Energy Systems, Space and Special Purposes Division Washington, DC 20545

R. T. Carpenter

G. P. Dix

T. J. Dobry, Jr.

N. Goldenberg

A. P. Litman (3)

J. J. Lombardo

G. A. Newby

D. J. Rock

E. J. Wahlquist

ERDA Division of Waste Management and Transportation Washington, DC 20545

R. W. Ramsey, Jr.

ERDA Oak Ridge Operations Office

P. O. Box E

Oak Ridge, TN 37830

D. C. Davis, Jr. 
No. of

Copies

3

170

1

1

1

1

1

3
ERDA Savannah River Operations Office P. 0. Box A

Aiken, SC 29801

R. H. Bass

T. B. Hindman

R. K. Huntoon

ERDA Technical Information Center

Department of the Army

Headquarters, U.S. Army

Facilities Engineering

Support Agency

Fort Belvoir, VA 22060

H. Musse1man, Technical Director

Electronics and Applied Physics Division

Building 347.3, AERE Harwel1

Oxfordshire 0X11 ORA

Great Britain

E. H. Cooke-Yarborough

General Atomic Company

P. 0. Box 81601

San Diego, CA 92138

H. C. Carney

General Electric Company MSVD

P. 0. Box 8555

Philadelphia, PA 19101

P. E. Brown

General Electric Company, Vallecitos Laboratory

P. 0. Box 846

Pleasanton, CA 94566

G. E. Robinson

Los Alamos Scientific Laboratory

P. 0. Box 1663

Los Alamos, NM 87544

S. E. Bronisz

R. A. Kent

R. N. Mulford 
No. of

Copies

1

Monsanto Research Corporation

Mound Laboratory (ERDA)

Nuclear Operations

P. 0. Box 32

Miamisburg, $\mathrm{OH} 45342$

W. T. Cave

1

Naval Nuclear Power Division

Ft. Belvoir, VA 22060

F. E. Roselle

3

Naval Facilities Engineering Command Nuclear Power Division (FACO42)

Washington, DC 20390

T. P. Fleming

G. E. Krauter

M. Starr

Navy Office of the Chief of Naval Operations

Washington, DC 20390

Head, Reactor Branch

4

Hol ifield National Laboratory

Oak Ridge, TN 37830

R. S. Crouse

J. R. Distefano

E. Lamb

A. C. Schaffhauser

3

Teledyne Energy Systems

110 W. Timonium Road

Timonium, MD 21093

P. Dick

R. Harınah

P. Vogelberger

1

Westinghouse Astronuclear Laboratory

P. 0. Box 10864

Pittsburgh, PA 15236

C. C. Silverstein 
No. of

Copies

ONSITE

2

8

23
ERDA Richland Operations Office

W. C. Johnson

B. J. Melton

Atlantic Richfield Hanford Company

L. I. Brecke

R. E. Isaacson

L. M. Knights

C. W. Malody

J. D. Moore

G. C. Oberg

H. P. Shaw

M. J. Szulinski

Battelle-Northwest

J. W. Bartlett

R. E. Burns

T. D. Chikalla

R. L. Dillon

J. W. Finnigan

H. T. Fullam (3)

A. J. Haverfield

J. H. Jarrett

R. S. Kemper

R. P. Marsha 11

R. W. McKee

J. M. Nielsen

R. E. Nightingale

L. D. Perrigo

A. M. Platt

J. L. Simmons

H. H. Van Tuyl

Technical Information Files (3)

Technical Publications 